perhaps indiscriminately so. The intended increase for exploration of the Solar System is welcome, but vulnerable on past form. What Congress should appreciate is that, by postponing projects, it makes them more expensive and less effective than they might be by the use of up-to-date techniques. And why, these days, should the mounting of the simplest extraterrestrial project take a decade or more? That is most of all apparent in the gathering of data about the global warming question, where there is now likely to be a hiatus until near the end of the decade. Yet the space station Freedom limps along, the lack of a clear definition of its purpose and the disaffection of potential international partners such as Germany notwithstanding. On the face of things, the Office of Management and Budget has failed to ask NASA the tough questions. Will Congress oblige instead?

By contrast, what the budget asks for science education may well go through on the nod. The parlous condition of public education, and of technical education in particular, is now widely acknowledged in the United States. In the past year or so, there has been a rash of initiatives by national laboratories and university departments to stimulate teachers in their neighbourhoods to more imaginative efforts. Now the administration proposes that both the NSF and the Department of Education should have substantially more to spend on the improvement of science education. If Congress agrees, Bush will have given back to NSF the influence that his predecessor took away.

Yet again there are structural problems, most of them linked with the constitutional role of increasingly cashstrapped state governments for educating their young. What the federal government needs is a lever by means of which its good intentions can be made reality. The postSputnik wave of curriculum development (sponsored largely by NSF) served that purpose in the 1960s, but its influence has petered out. This time around, there may be more to be said for direct financial support for graduate students and intending science teachers. But, with a planned federal budget for science education of nearly $\$ 2,000$ million next year, the administration might at least say in clear language what it hopes to accomplish. No doubt even Congress would like to be told.

That same questions bears on what the United States seeks to accomplish by its willingness to support research. Since President Ronald Reagan came to office ten years ago, the record is remarkable, Lederman's objections notwithstanding. For much of the time, the justification has been 'competitiveness' - the belief that the United States cannot hope to keep its trade balance in the black without research. That the belief is correct is demonstrated by the continuing success of, say, the computer industry, but the connection rests as much on the skilled people as on the discoveries that research produces. But 'leadership' has been a common sub-theme, leading to escapades such as the space station, which engage able people unproductively. Should the US government now be more discriminating in its generosity?

\section{Europe's non-defence}

Europe's diffidence over mutual defence casts a shadow over federalist ambitions.

THE most obvious casualty of the Gulf War so far is the dream of many in Europe that the true common market planned for 1993 will be quickly followed by more general integration. For a start, the two intergovernmental conferences (on monetary and political union) set up at the Rome meeting last December have been virtually killed off by the well-known phenomenon that governments can pay close attention to only one thing at a time. But the desultory proceedings of the conference on political union have already made it plain that Europe is far from ready to act as a federation.

The issue is whether economically integrated Europe should have a common defence policy. As things are, there are arrangements within the European Communities (EC) for coordination on foreign policy; from time to time, foreign ministers jointly issue declarations on important issues such as events in Tiananmen Square in 1989 and the more recent upheavals in Eastern Europe. Federalists have regarded these declarations, anodyne as they have often been, as signs that more substantial common policies might eventually be fashioned. But enough governments have now made plain their discontent with the notion of a common defence policy for an amendment of the Treaty of Rome to be rendered unattainable.

What seems not to be appreciated is that the question can be answered negatively only by endangering even the economic union on which the EC is embarked. For how can a dozen countries hang indefinitely together without a general understanding that all would fly to help a fellowmember attacked from outside? Otherwise, some member states might suffer the economic disadvantages of having to defend themselves while their fellowmembers profit by manufacturing and selling them military equipment. That is the lowest common denominator of the case for regarding a mutual defence agreement as an indispensable part of economic union going beyond a mere customs union. But in addition, if federal Europe is meant to be the cultural and social unity implied even by the present freedom of people to work where they choose, how can it be thought that parts of it could be amputated at the will of outsiders?

For much of the past year Europe has believed that such happenings were things of the past. Now it is not so sure. The Gulf War, involving both Britain and France, has been a further shock. Germany, preoccupied with reunification, is plainly embarrassed by this show of what seems to be bellicosity. Further, should Turkey be attacked, Germany's obligations under the NATO treaty require that it follow suit. Britain, never federalist, is unsurprised. France, forever hoping the EC would cement Germany into a larger Europe, is dismayed. But in the end, Europe as a whole will be the loser. 